\title{
STRATEGI PEMASARAN PRODUK CAT OZONE DI SEKTOR RETAIL UNTUK WILAYAH JAKARTA, DEPOK, TANGERANG, DAN BEKASI PERIODE 2012-2014
}

\author{
Edbert Mulyadi \\ Program Studi S2 MM WM 63 \\ Sekolah Tinggi Manajemen PPM \\ Meinita Nurul R. \\ Program Studi S2 MM WM 63 \\ Sekolah Tinggi Manajemen PPM
}

\begin{abstract}
Perkembangan penjualan produk cat tembok dalam industri mengalami peningkatan setiap tahunnya. Pada tahun 2011 diperkirakan mengalami perkembangan sebesar $8.01 \%$. Namun, perusahaan Sumi Asih sebagai produsen cat tembok Ozone mengalami tren penurun penjualan mulai tahun 2009 sampai 2010, selain itu saat ini perusahaan belum memiliki STP dan strategi untuk mengahadapi persaingan. Kondisi ketersediaan produk cat Ozone hanya terbatas pada toko bangunan tradisional dan belum terdapat di toko bangunan modern, selain itu persentase ketersediaan di wilayah Jadetabek adalah sebesar $1.06 \%$ dan tingkat awareness dikalangan pemilik toko bangunan dan pengguna akhir cat tembok yang masih rendah. Karakteristik persaingan dalam industri cat tembok memiliki intensitas yang tinggi. Pesaing utama produk cat Ozone adalah Vinilex dan Catylac yang memiliki keunggulan dalam hal distribusi dan awareness. Hal tersebut merupakan tantangan bagi produk cat Ozone sebagai cat tembok yang baru beredar di pasaran retail mulai tahun 2009 untuk dapat meningkatkan penjualan dan market share. Dari hasil analisis, didapatkan strategi marketing terpilih untuk dapat mencapai sasaran perusahaan adalah mengkomunikasikan keunggulan dari produk cat Ozone berupa daya tutup yang baik, cat tembok anti bakteri dan sudah digunakan pada gedung-gedung ternama melalui media elektronik, media cetak, dan mengikuti pameran serta memperbaiki kualitas produknya yang diikuti pula dengan memperluas jalur distribusi ke toko bangunan tradisional dan modern.
\end{abstract}

Keywords:

Strategi Pemasaran, Produk Cat Tembok. 


\section{PENDAHULUAN}

Dalam dua tahun terakhir ini, industri cat dan coating mengalami ketidakpastian. Pada awal 2009 industri ini mengalami keterpurukan karena penjualan cat selama Januari dan Februari 2009 mengalami penurunan sekitar $10-15$ persen dibanding bulan yang sama 2008 silam, namun mampu untuk bangkit kembali diakhir tahun 2009.
Konsumsi cat nasional tahun 2011 diproyeksikan naik mencapai 740.142 ton atau meningkat sebesar $7.44 \%$ dibandingkan tahun 2010, sedangkan tahun 2010 konsumsi cat hanya sebesar 688.863 ton dan tahun 2009 sebesar 646.700 ton. Saat ini tingkat konsumsi pada tahun 2011 masih akan didominasi oleh cat tembok cair (wall paint water) yang akan diproyeksi akan mencapai 509.377 ton. Sedangkan pada tahun lalu hanya sebesar 471.590 ton dan 444.477 pada 2009.

Tabel 1.

Penjualan dan Pertumbuhan Industri Cat di Indonesia Tahun 2009 dan 2010

\begin{tabular}{|l||r||r|r|r|r||}
\hline \multicolumn{1}{|l|}{} & 2009 (ton) & $\mathbf{2 0 1 0}$ (ton) & Prediksi 2011 & Growth 2010 & Growth 2011 \\
\hline \hline Other Ind. & 12.370 & 13.235 & 14.304 & $6,99 \%$ & $8,08 \%$ \\
\hline Wood Coatings & 67.677 & 70.414 & 72.047 & $4,04 \%$ & $2,32 \%$ \\
\hline Protective Coatings & 14.900 & 16.943 & 18.290 & $13,71 \%$ & $7,95 \%$ \\
\hline Powder Coatings & 5.511 & 6.396 & 6.907 & $16,06 \&$ & $7,99 \%$ \\
\hline Marine Coatings & 4.683 & 5.510 & 6.050 & $17,66 \%$ & $9,80 \%$ \\
\hline \hline Coil Coatings & 2.782 & 3.176 & 3.438 & $14,16 \%$ & $8,25 \%$ \\
\hline Can Coatings & 4.307 & 4.808 & 5.198 & $11,63 \%$ & $8,11 \%$ \\
\hline Auto Refinish & 11.506 & 12.311 & 13.293 & $7,00 \%$ & $7,98 \%$ \\
\hline \hline Auto OEM & 12.071 & 12.915 & 13.948 & $6,99 \%$ & $8,00 \%$ \\
\hline Decoratif Paint (Solvent) & 66.416 & 71.565 & 77.290 & $7,75 \%$ & $8,00 \%$ \\
\hline Wall Paint (water) & 444.477 & 471.590 & 509.377 & $6,10 \%$ & $8,01 \%$ \\
\hline TOTAL & 646.700 & 688.863 & 740.142 & & \\
\hline
\end{tabular}

Sumber : Asosiasi Cat Indonesia

Dari data Tabel 1. di atas terlihat bahwa produk cat tembok masih mendominasi penjualan dalam industri cat dan diprediksi akan berkembang karena konsumsi cat tembok akan meningkat. Sehingga dapat disimpulkan bahwa masih terdapat peluang bagi pemain industri cat untuk memperoleh keuntungan dari fenomena meningkatnya konsumsi cat tembok.

Namun disisi lain, industri cat memiliki ancaman dengan berlakunya Peraturan Menteri Keungan (PMK) no. 241 tahun 2010 tentang Penetapan Sistem Klasifikasi Barang dan Pembebanan Tarif
Bea Masuk atas Barang Impor, jika sebelumnya tidak dikenakan bea masuk, mulai 22 Desember 2010 impor bahan baku cat dikenakan BM 5\%. Hal tersebut dirasa memberatkan bagi produsen cat karena sebagian besar bahan baku cat masih di impor dan akibatnya adalah keuntungan yang semakin berkurang.

Selain adanya ancaman pemberlakuan PMK, produsen cat juga menghadapi ancaman dari pemberlakuan China-Asean Free Trade Agreement (CAFTA) membuat industri cat nasional menjadi kurang berdaya saing. Kenaikan bea masuk dari bahan baku membuat harga cat 
tembok menjadi mahal, sehingga kalah bersaing dengan produk cat tembok impor yang bebas tarif.

Saat ini, Departemen Perindustrian dan Perdagangan mencatat, jumlah produsen negeri mencapai 30 perusahaan. Namun, pemerintah menemukan jumlah cat yang beredar di dalam negeri jauh lebih besar dari produksi nasional. Didalam industri cat terdapat banyak pemain dengan berbagai merek. Beberapa merek terdapat dalam satu pabrik yang sama. Persaingan dalam industri cat dapat dibagi menjadi tiga kelas, yaitu top tier, mid tier dan low tier. Pembagian kelas tersebut berasal dari penelitian yang pernah dilakukan oleh perusahaan pada tahun 2006 . Berikut ini nama merek cat tembok yang bermain di toko bangunan tradisional.

Tabel 2.

Pemain dalam Industri Cat Tembok

\begin{tabular}{|c|c|c|c|c|c|c|c|}
\hline \multicolumn{2}{|r|}{ Top Tier } & \multicolumn{4}{|c|}{ Mid Tier } & \multicolumn{2}{|r|}{ Low Tier } \\
\hline 1 & Nippon Spotless & 7 & Super Vinilex & 13 & Danabrite & 18 & Par (ICI) \\
\hline 2 & Dulux Pentalite & 8 & Catylac & 14 & Property (Kansai) & 19 & Aries (Avian) \\
\hline 3 & Mowilex & 9 & Metrolite & 15 & Jotaplast (Jotun) & 20 & Q-Luc (Nippon) \\
\hline 4 & Danactyl & 10 & Cendana (Mowilex) & 16 & Lenkote (Jasmine) & 21 & Globe (Alfa Tunggal) \\
\hline 5 & Jatatough & 11 & Fres (Avian) & 17 & Ozone & 22 & Bumilex \\
\hline 6 & Diamond & 12 & Decolith & & & 23 & Parmatex \\
\hline
\end{tabular}

Sumber : hasil riset yang dilakukan perusahan 2006

PT. Sumi Asih yang bergerak di bidang Oleochamical yang juga memproduksi cat tembok dengan merek Ozone harus mampu memanfaatkan peluang dari prediksi pertumbuhan konsumsi cat tembok sebesar $8.01 \%$ pada tahun 2011 ini. Cat Ozone baru masuk ke dalam bisnis retail mulai Agustus 2009, walaupun untuk bisnis project sudah dimulai pada tahun 2008 .
Berikut ini merupakan grafik yang menunjukan kondisi penjualan produk cat Ozone untuk retail dan hanya terbatas pada wilayah Jakarta, Bekasi, Depok dan Tangerang pada tahun 2009 dan 2010 yang akan dibagi per bulan (Gambar 1. dan Gambar 2.).

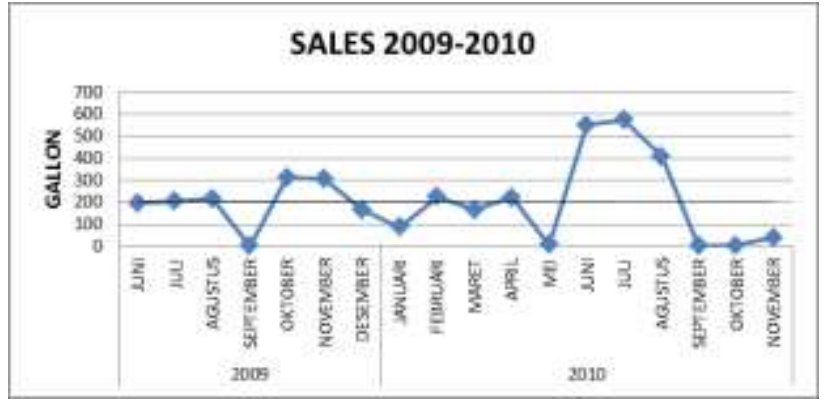

Gambar 1.

Penjualan Produk cat Ozone Tahun 2009-2010 dalam Gallon 


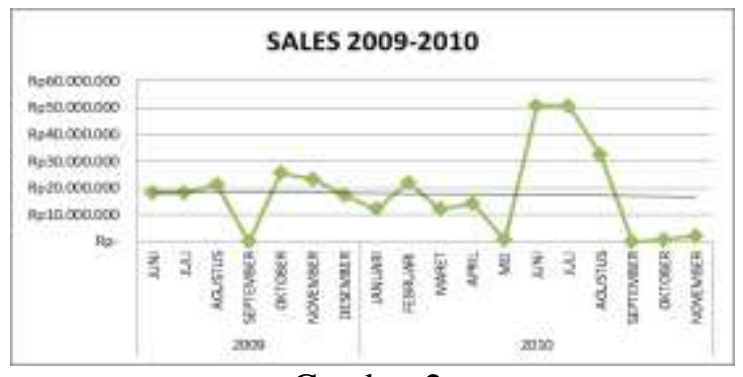

Gambar 2.

Penjualan Produk Cat Ozone Tahun 2009-2010 dalam Rupiah

Dari hasil rekapitulasi penjualan pada tahun 2009 dan 2010, diketahui bahwa pada bulan September selalu menunjukan tidak ada penjualan (0 gallon) di dalam bulan tersebut. Sedangkan jika dilihat dari trend penjualan tahun 2009-2010 menunjukkan penurunan.

Berdasarkan hasil riset ekspolatori yang dilakukan oleh penulis dengan narasumber pemilik toko bangunan di wilayah Jakarta, Depok, Tangerang dan Bekasi, kondisi Ozone saat ini menunjukan banyak produk yang ditarik dari toko karena barangnya tidak laku, sedangkan toko bangunan yang masih menjual Ozone manyatakan bahwa sulit untuk menjual produk cat Ozone karena konsumen tidak mengenal mereknya. Akibatnya, produk cat Ozone menjadi kurang laku di pasar retail.
Sesuai dengan pembagian kelas pada produk cat tembok, Ozone termasuk kedalam kelas Mid Tier. Perusahaan menyimpulkan bahwa terdapat dua pesaing terdekat dari Ozone untuk kelas Mid Tier, yaitu Vinilex dan Catylac. Hal tersebut dikarenakan kedua merek tersebut masih dalam kisaran harga Rp.70.000 sampai Rp.80.000 dan kualitas yang hampir sama. Dari hasil riset yang dilakukan sebelumnya dengan responden pemilik toko bangunan diketahui persentase ketersediaan dari masing-masing produk cat tembok serta market share index. Jika dibandingkan dengan pesaing yaitu Vinilex dan Catylac, posisi Ozone saat ini masih dibawah kedua merek tersebut. Hal tersebut dapat dilihat dari persentase ketersedian (Tabel 3.) dan market share index seperti yang digambarkan pada Tabel 4. di bawah ini.

Tabel 3.

Persentase Ketersediaan Produk Cat Ozone, Vinilex dan Catylac

\begin{tabular}{||l||r|r|}
\hline \multicolumn{1}{|c|}{ Brand } & Jumlah & Presentase Ketersedian \\
\hline Ozone & 13 & $16,88 \%$ \\
\hline \hline Vinilex & 71 & $92,21 \%$ \\
\hline \hline Catylac & 48 & $62,34 \%$ \\
\hline
\end{tabular}

Tabel 4.

Market Share Index Produk Cat Ozone, Vinilex dan Catylac

\begin{tabular}{|l|r|}
\hline \multicolumn{1}{|c|}{ Brand } & Market Share Index \\
\hline \hline Vinilex & $80,23 \%$ \\
\hline \hline Catylac & $56,98 \%$ \\
\hline \hline Ozone & $3,49 \%$ \\
\hline
\end{tabular}


Dapat dilihat bahwa dari persentase ketersediaan produk cat tembok dan market share index, Ozone masih di posisi terbawah dan memiliki selisih yang cukup jauh dengan pesaingnya. Untuk memenangkan persaingan dan menyamakan posisi dengan kedua pesaingnya memang cukup sulit, apalagi jika dilihat kedua pemain tersebut sudah puluhan tahun bermain dalam industri cat tembok dan merek mereka sudah melekat di benak konsumen. Namun, bukan tidak mungkin bagi perusahaan untuk berkembang dalam industri tersebut dan tentunya dengan strategi yang dimiliki.

Kondisi industri yang diprediksi akan berkembang dengan pertumbuhan 3 sampai $4 \%$ serta masih akan meningkatnya permintaan dari konsumen. Kenaikan permintaan konsumen tersebut dapat diketahui dari sektor perumahan tahun 2011 yang akan diperkirakan tumbuh sebesar $15 \%$ dari tahun 2011. Hal tersebut didapatkan dari Ketua Umum Real Estate Indonesia (REI) Setyo Maharso. Sehingga dapat disimpulkan bahwa perusahaan masih memiliki peluang untuk berkembang. Namun, untuk memanfaatkan peluang tersebut, perusahaan harus memiliki strategi pemasaran yang didukung pula oleh segementasi, positioning dan targeting yang tepat.

Berdasarkan dari alasan tersebut maka perusahaan membutuhkan riset mengenai segmentasi, targeting dan juga positioning dari produk cat Ozone. Dengan tersedianya analisis tersebut diharapkan perusahaan mampu meningkatkan penjualan.

Untuk mendapatkan segementasi, targeting dan positioning produk cat Ozone, perusahaan juga harus mengetahui persepsi dari retailer maupun pengguna akhir cat tersebut. Sehingga dalam hal ini, riset proses pembuatan keputusan konsumen dalam pemilihan cat tembok menjadi sangat penting dalam penyusunan strategi pemasaran untuk retailer (toko bangunan).
Sehingga diharapkan dengan menerapkan strategi pemasaran yang sesuai dengan segmentasi, targeting dan positioning dari produknya maka penjualan akan semakin meningkat dan disertai pula dengan efisiensi biaya karena mampu melakukan pemasaran yang tepat sasaran.

Berdasarkan data yang diapaparkan di atas dapat diambil keimpulan bahwa produk cat Ozone membutuhkan sebuah strategi pemasaran apabila ingin meningkatkan market share dan penjualan.

\section{TINJAUAN PUSTAKA}

\subsection{Analisis Eksternal}

Menurut Fred. R. David, tujuan dari analisis eksternal adalah untuk mengembangkan daftar peluang yang dapat dimanfaatkan oleh perusahaan dan ancaman yang harus dihindari. Dalam bukunya juga menyebutkan bahwa terdapat metode analisis yang dapat digunakan, antara lain:

a. Faktor politik, pemerintah dan regulasi.

b.Faktor ekonomi.

c. Faktor sosial, budaya, demografi dan lingkungan.

d.Faktor teknologi.

e. Faktor kompetisi.

Dalam penelitian ini poin a sampai d akan dikategorikan menjadi analisis PEST sedangkan faktor kompetisi akan dianalisis menggunakan Porter's five forces model.

Selain dua metode analisis tersebut, dalam penelitian ini juga menggunakan analisis pasar yaitu decision making process dengan teori Hawkins.

\subsection{Analisis Internal}

Analisis internal yang digunakan dalam penulisan meliputi analisis posisi, perbandingan dengan pesaing, serta evaluasi program pemasaran. Untuk analisis posisi digunakan teori share performance metrics 
dan competitive profile matrix (CPM). Menurut Roger J. Best (2009) share performance metrics menunjukkan proses dari estimasi indeks pangsa pasar berdasarkan pangsa pasar matrik sekuensial.

\subsection{Kerangka Analisis}

Berikut pada Gambar 3. dapat dilihat kerangka analisis penelitian ini.

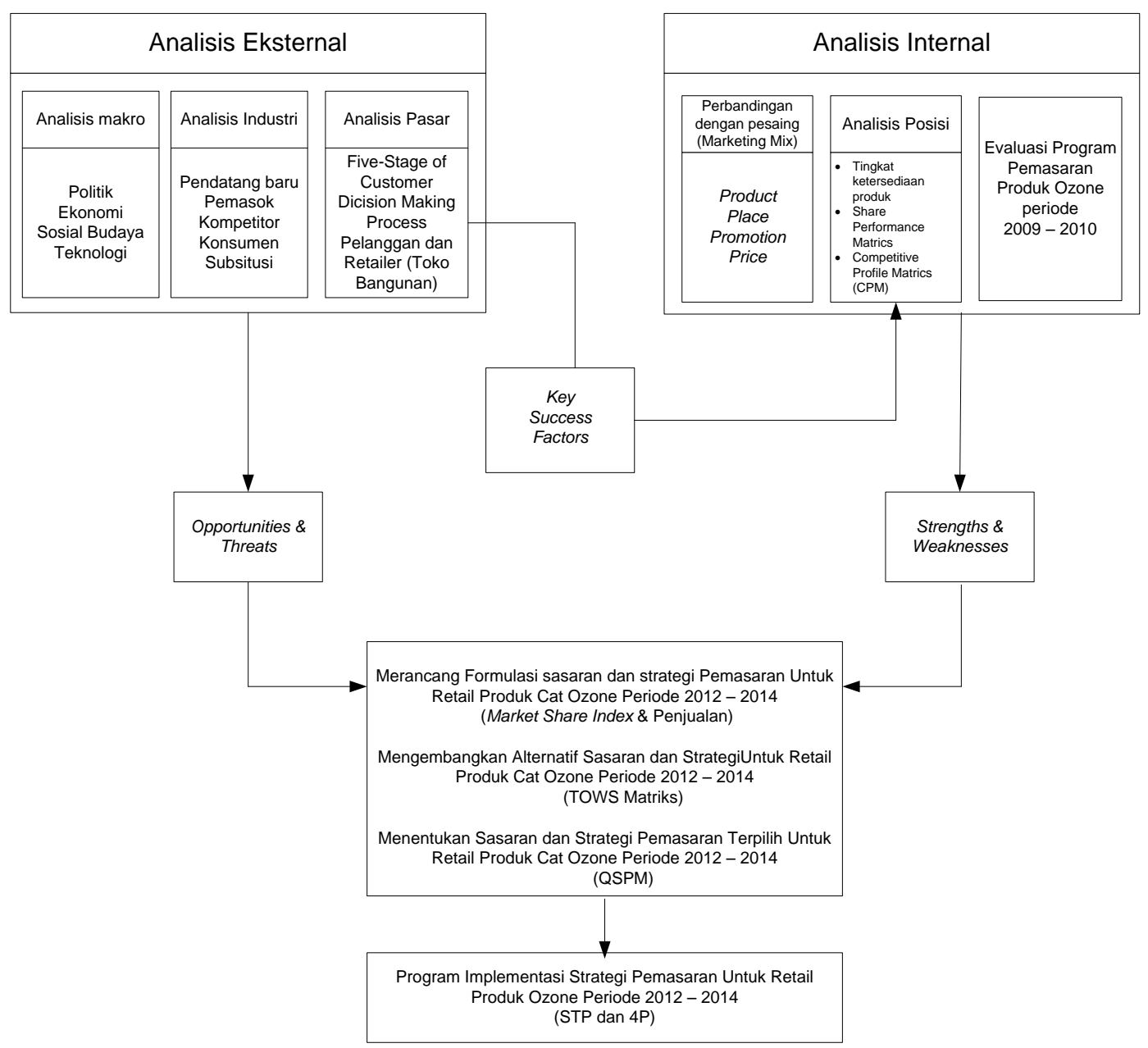

Gambar 3.

Kerangka Analisis Penelitian

\section{METODOLOGI}

Penelitian ini menggunakan teori utama dari Fred David, maka untuk analisis ekstrenal meliputi analisis PEST, analisis industri (menggunakan analisis five forces porter) dan penelitian ini juga menggunakan menggunakan metode eksploratori riset untuk mengetahui consumer decision making process dari pemilik toko bangunan dan pengguna akhir cat tembok. Riset tersebut juga dapat mengetahui preferensi dari masing-masing populasi. 
Metode pengumpulan data pada tesis ini adalah dengan mengunakan data primer dan sekunder. Data primer, yaitu data yang diperoleh secara langsung dari sumbernya. Berdasarkan sifatnya data primer bisa dikategorikan menjadi dua macam yaitu data kualitatif dan data kuantitatif. Metode yang digunakan adalah wawancara, penyebaran kuesioner, blind test dan observasi.

Data sekunder, diperoleh dari data internal objek penelitian yaitu dari perusahaan, dalam bentuk daftar retailer dan data penjualan. Sedangkan data yang berisi dari eksternal yaitu literatur, buku-buku, koran, majalah, internet, jurnal, serta hasilhasil riset lainnya yang terkait dengan penelitian. Data sekunder yang diperoleh digunakan untuk mendukung data primer.

\section{HASIL DAN PEMBAHASAN}

\subsection{Analisis Eksternal}

Berdasarkan analisis eksternal dengan menggunakan metode analisis PEST, analisis industri dan consumer decision making process, maka berikut ini merupakan peluang dan acaman untuk industri cat tembok di sektor retail:

- Peluang

- Dengan berlakunya peraturan SNI maka pemerintah akan memusnahkan beberapa merek cat tembok non standar sehingga jumlah merek cat tembok yang beredar semakin berkurang.

- Perkiraan pertumbuhan perumahan pada tahun 2011 meningkat $15 \%$ dan didukung oleh tren inflasi selama lima tahun terakhir yang menurun dapat meningkatkan permintaan akan cat tembok di masa yang akan datang.

- Peningkatan pasar cat dan coating di Asia Pasifik sebesar 5\% menunjukkan potensi ekspansi dan ekspor produsen cat tembok dalam negeri.
- Indonesia masih harus mengimpor sekitar 100.000 ton per tahun untuk produk cat tertentu sehingga masih terdapat potensi pasar yang belum terlayani.

- Sebagian besar dari konsumen melakukan pengecetan ulang kurang dari satu tahun dan satu tahun sekali yang dapat meningkatkan frekuensi pembelian dari produk cat tembok.

- Banyak dari konsumen tidak hanya membeli produk cat tembok di toko material, namun membeli di toko bangunan modern sehingga produsen cat tembok dapat lebih memperluas jalur distribusi.

- Ancaman

- Diberlakukannya CAFTA membuat pemain asing mudah masuk dalam industri cat tembok.

- Adanya bea masuk untuk bahan baku cat tembok dari $0 \%$ menjadi $5 \%$ yang dapat menyebabkan harga jual semakin meningkat sehingga daya beli masyarakat terhadap produk cat tembok semakin menurun.

- Perilaku konsumen yang cenderung melakukan perbandingan harga sebelum membeli memaksa produsen membuat harga jual dari produk cat tembok kompetitif.

- Biaya beralih ke produk cat tembok lain hampir tidak ada, kemudahan informasi serta banyak bermunculan merek-merek baru membuat konsumen memiliki banyak pilihan dan berpindah-pindah ke produk cat tembok lainnya.

- Sulit merubah persepsi masyarakat terhadap produk cat tembok baru sehingga menyebabkan merek baru sulit dijual.

- Tindakan yang dilakukan oleh konsumen ketika merasa kurang puas atas suatu produk cat tembok adalah memberitahukan kepada konsumen lain 
sehingga nama baik dari produk tersebut menjadi semakin buruk yang mengakibatkan konsumen beralih ke produk cat tembok lainnya.

- Semakin berkembangnya produk substitusi berupa wallpaper, parquet, batu alam, bata expose, dan high pressure laminate yang mengakibatkan kemungkinan tergantikannya fungsi cat tembok di masa yang akan datang.
Setelah mengetahui peluang dan ancaman maka perlu diketahui key success factors untuk industri tersebut. Dalam hal ini pertanyaan riset yang menjadi dasar dalam penyusunan Key Success Factors adalah preferensi atau tingkat kepentingan pemilik toko bangunan terhadap pemilihan suatu merek cat tembok yang akan dijual di toko (Tabel 5.) dan preferensi dari pengguna akhir cat tembok Tabel 6.). Dalam hal ini diambil nilai rata-rata yang paling tinggi.

Tabel 5.

Preferensi Pemilik Toko Bangunan dalam Pemilihan Produk Cat Tembok

\begin{tabular}{|l||r||}
\hline \multicolumn{1}{|c||}{ Preferensi } & Rata-rata \\
\hline \hline Merek produk terkenal & 4,47 \\
\hline \hline Produk yang ditawarkan berkualitas & 4,39 \\
\hline \hline Harga yang sesuai dengan konsumen & 4,03 \\
\hline \hline Warna yang ditawarkan bervariasi & 3,75 \\
\hline \hline Potongan harga yang ditawarkan besar & 3,52 \\
\hline \hline Iklan yang menarik & 3,36 \\
\hline \hline Sales yang ramah/menarik & 3,36 \\
\hline \hline Penawaran promo hadiah langsung menarik & 3,32 \\
\hline \hline Produk yang ditawarkan bervariasi & 3,03 \\
\hline \hline Ketersediaan mesin tinting/oplos & 2,86 \\
\hline \hline
\end{tabular}

Jika dilihat dari empat nilai tertinggi rata-rata respon responden untuk preferensi pemilihan produk cat tembok berdasarkan pemilik toko bangunan antara lain:

- Merek produk terkenal

- Produk yang ditawarkan berkualitas
- Harga yang sesuai dengan konsumen

- Warna yang ditawarkan bervariasi

Sedangkan untuk Key Success Factors berdasarkan hasil riset dengan responden pengguna akhir cat tembok adalah:

Tabel 6.

Preferensi Pengguna Akhir Cat dalam Pemilihan Produk Cat Tembok

\begin{tabular}{|l|r||}
\hline \multicolumn{1}{|c||}{ Preferensi } & \multicolumn{1}{|r|}{ Rata-rata } \\
\hline \hline Produk yang ditawarkan berkualitas & 5,12 \\
\hline \hline Cat memiliki daya tutup yang baik & 5,06 \\
\hline \hline Harga sesuai dengan konsumen & 4,90 \\
\hline \hline Pemilik toko bangunan mau memberikan informasi & 4,84 \\
\hline \hline Toko bangunan mudah dijangkau & 4,78 \\
\hline \hline Warna yang ditawarkan bervariasi & 4,75 \\
\hline \hline Potongan harga besar (diskon dari toko) & 4,50 \\
\hline \hline Cat mengandung anti bakteri & 4,38 \\
\hline
\end{tabular}




\begin{tabular}{|l|r|}
\hline Ketersediaan mesin tinting/oplos & 4,07 \\
\hline \hline Iklan yang menarik di media & 3,91 \\
\hline \hline Merek produk terkenal & 3,79 \\
\hline \hline Penawaran promo (hadiah langsung) menarik & 3,69 \\
\hline \hline Ada undian berhadiah & 3,59 \\
\hline \hline Cat wangi & 3,53 \\
\hline \hline Kemasan menarik & 3,22 \\
\hline
\end{tabular}

Jika dilihat dari empat nilai rata-rata tertinggi respon responden untuk preferensi pemilihan produk cat tembok berdasarkan pengguna akhir cat tembok antara lain:

- Produk yang ditawarkan berkualitas

- Cat memiliki daya tutup yang baik

- Harga sesuai dengan konsumen

- Pemilik toko bangunan mau memberikan informasi

\subsection{Analisis Internal}

Analisis internal digunakan untuk mengetahui kekuatan dan kelemahan dari perusahaan. Dalam hal ini digunakan analisis perbandingan dengan pesaing utamanya yaitu Vinilex dan Caytlac yaitu berdasarkan marketing mix untuk kedua merek tersebut. Selain itu, digunakan pula metode
Competitive Profile Matrix (CPM) yang didapat dari analisis responden yang melakukan pembobotan dan membandingkan merek cat Ozone dengan kedua pesaing utamanya. Metode lainnya dalam analisis internal adalah evalusi program pemasaran yang sudah dilakukan oleh perusahaan..

Pada Tabel 3. ditunjukkan persentase ketersediaan Ozone di wilayah Jadetabek paling rendah jika dibandingkan oleh Vinilex dan Catylac.

Penelitian ini juga dilengkapi oleh blind test terhadap ketiga merek tersebut. Aspek yang diteliti dalam blind test antara lain daya tutup, aroma serta kehalusan permukaan. Hasil dari blind test terdapat pada tabel 7. dibawah ini.

Tabel 7.

Perbandingan Skala Evaluasi Pesaing dari Hasil Blind Test

\begin{tabular}{|l|r||r||r||}
\hline & \multicolumn{1}{|c|}{ Catylac } & \multicolumn{1}{c|}{ Vinilex } & \multicolumn{1}{c|}{ Ozone } \\
\hline \hline Daya tutup lapis 1 & 3,96 & 3,54 & 4,34 \\
\hline \hline Daya tutup lapis 2 & 4,02 & 3,56 & 4,38 \\
\hline \hline Daya tutup lapis 3 & 4,02 & 3,58 & 4,44 \\
\hline \hline Aroma & 4,29 & 4,10 & 3,29 \\
\hline \hline Kehalusan permukaan & 3,98 & 4,18 & 3,75 \\
\hline
\end{tabular}

Jika dilihat dari hasil persepsi responden terhadap sampel basah dan kering, produk cat Ozone memiliki nilai rata-rata paling baik untuk daya tutup jika dibandingkan dengan merek Catylac dan Vinilex. Namun, dari segi aroma nilai ratarata produk cat Ozone paling rendah, beberapa konsumen merasa bahwa aroma dari produk cat Ozone kurang enak sedangkan Catylac memiliki aroma yang wangi sehingga digemari oleh para responden.

Untuk kehalusan permukaan, produk cat Vinilex memiliki nilai rata-rata yang terbaik dan produk cat Ozone dengan ratarata yang paling kecil. Responden mengatakan bahwa walaupun produk cat Vinilex memiliki tingkat kehalusan yang 
baik namun memiliki kelemahan setelah cat diaplikasikan terlihat tipis.
Pada Tabel 8. akan diuraikan hasil riset mengenai ringkasan share performance matrix dari 2 populasi.

Tabel 8.

Market Share Index Ozone, Vinilex, dan Catylac

\begin{tabular}{|l||r||r|r||r|r|r||}
\hline \multirow{2}{*}{$\begin{array}{c}\text { Share Performance } \\
\text { Matrix }\end{array}$} & \multicolumn{2}{|c|}{ Pemilik Toko Bangunan } & \multicolumn{2}{|c|}{ Pengguna Akhir Cat Tembok } \\
\cline { 2 - 7 } & Ozone & Vinilex & Catylac & \multicolumn{1}{c|}{ Ozone } & \multicolumn{1}{c|}{ Vinilex } & \multicolumn{1}{c|}{ Catylac } \\
\hline \hline Product awareness & $27,90 \%$ & $100,00 \%$ & $98,80 \%$ & $33,82 \%$ & $72,06 \%$ & $95,59 \%$ \\
\hline \hline Product attractiveness & $87,50 \%$ & $93,00 \%$ & $63,50 \%$ & $100,00 \%$ & $65,31 \%$ & $72,31 \%$ \\
\hline \hline Price affordable & $33,30 \%$ & $95,00 \%$ & $90,70 \%$ & $91,30 \%$ & $96,88 \%$ & $95,74 \%$ \\
\hline \hline Product availability & & & & $52,38 \%$ & $93,55 \%$ & $91,11 \%$ \\
\hline Service experience & $42,90 \%$ & $90,80 \%$ & $100,00 \%$ & $81,82 \%$ & $72,41 \%$ & $95,12 \%$ \\
\hline \hline Market Share Index & $3,49 \%$ & $80,22 \%$ & $56,90 \%$ & $13,24 \%$ & $30,88 \%$ & $57,35 \%$ \\
\hline \hline
\end{tabular}

Dari hasil perhitungan market share index dengan populasi pemilik toko bangunan antara tiga merek tersebut, diketahui bahwa masih produk cat Vinilex yang mempati posisi pertama dengan persentase $80.23 \%$ dan yang kedua adalah produk cat Catylac dengan $56.98 \%$ lalu produk cat Ozone di posisi terakhir dengan market share hanya $3.49 \%$.
Kondisi market share index sedikit berbeda untuk hasil riset dengan populasi pengguna akhir cat tembok, produk cat Catylac merupakan cat tembok dengan market share yang paling tinggi dibandingkan dengan kedua pesaingnya dengan nilai 57.35\%. Produk Vinilex memiliki angka market share index sebesar $30.88 \%$ dan produk cat Ozone masih diposisi ketiga dengan market share index $13.24 \%$.

Tabel 9.

Competitive Profile Matrix Berdasarkan Hasil Riset Pemilik Toko Bangunan

\begin{tabular}{|c|c|c|c|c|c|c|c|c|c|}
\hline \multirow[t]{2}{*}{ No } & \multirow{2}{*}{$\begin{array}{c}\text { Key } \\
\text { success } \\
\text { factors }\end{array}$} & \multirow{2}{*}{$\begin{array}{c}\text { Rata-rata } \\
\text { tingkat } \\
\text { kepentingan } \\
\text { (A) }\end{array}$} & \multirow{2}{*}{$\begin{array}{c}\begin{array}{c}\text { Bobot } \\
(\mathbf{B})\end{array} \\
=(\mathbf{A}) / \text { total }(\mathbf{A})\end{array}$} & \multicolumn{2}{|c|}{ Ozone } & \multicolumn{2}{|c|}{ Vinilex } & \multicolumn{2}{|c|}{ Catylac } \\
\hline & & & & $\begin{array}{l}\text { Rata-rata } \\
\text { responden } \\
\text { (C) }\end{array}$ & $\begin{array}{c}\text { Weight } \\
\text { score }(\mathrm{D}) \\
=(\mathrm{B}) \mathbf{x}(\mathrm{C})\end{array}$ & $\begin{array}{l}\text { Rata-rata } \\
\text { responden } \\
\text { (E) }\end{array}$ & $\begin{array}{c}\text { Weight } \\
\text { score }(\mathbf{F}) \\
=(\mathbf{B}) \mathbf{x}(\mathbf{E})\end{array}$ & $\begin{array}{c}\text { Rata-rata } \\
\text { responden } \\
\text { (G) }\end{array}$ & $\begin{array}{c}\text { Weight } \\
\text { score }(\mathbf{H}) \\
=(\mathbf{B}) \mathbf{x}(\mathbf{G})\end{array}$ \\
\hline 1 & $\begin{array}{l}\text { Merek } \\
\text { produk } \\
\text { terkenal }\end{array}$ & 4,47 & 0,27 & 2 & 0,54 & 5 & 1,34 & 5 & 1,34 \\
\hline 2 & $\begin{array}{l}\text { Produk } \\
\text { yang } \\
\text { ditawarkan }\end{array}$ & 4,39 & 0,26 & 4 & 1,06 & 5 & 1,32 & 5 & 1,32 \\
\hline 3 & $\begin{array}{l}\text { Harga yang } \\
\text { sesuai } \\
\text { dengan } \\
\text { konsumen } \\
\end{array}$ & 4,03 & 0,24 & 3 & 0,73 & 5 & 1,21 & 4 & 0,97 \\
\hline 4 & $\begin{array}{l}\text { Warna } \\
\text { yang } \\
\text { ditawarkan } \\
\text { bervariasi } \\
\end{array}$ & 3,75 & 0,23 & 4 & 0,90 & 5 & 1,13 & 5 & 1,13 \\
\hline & Total & 16,64 & & & 3,22 & & 5,00 & & 4,76 \\
\hline
\end{tabular}


Tabel 9. menunjukan perbandingan yang dilakukan oleh pemilik toko bangunan, hasilnya dapat dilihat bahwa Vinilex memiliki nilai yang tinggi dibandingkan dengan kedua pesaingnya, di posisi kedua adalah merek Catylac dengan total nilai 4.76 dan Ozone di posisi paling rendah dengan nilai 3.22 .

Tabel 10.

Competitive Profile Matrix Berdasarkan Hasil Riset Pengguna Cat Tembok

\begin{tabular}{|c|c|c|c|c|c|c|c|c|c|}
\hline \multirow[t]{2}{*}{ No } & \multirow{2}{*}{$\begin{array}{c}\text { Key success } \\
\text { factors }\end{array}$} & \multirow{2}{*}{ 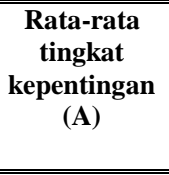 } & \multirow{2}{*}{$\begin{array}{c}\begin{array}{c}\text { Bobot } \\
(\text { B })\end{array} \\
=(\mathbf{A}) / \text { total } \\
\text { (A) }\end{array}$} & \multicolumn{2}{|c|}{ Ozone } & \multicolumn{2}{|c|}{ Vinilex } & \multicolumn{2}{|c|}{ Catylac } \\
\hline & & & & $\begin{array}{l}\text { Rata-rata } \\
\text { respon } \\
\text { responden } \\
\text { (C) }\end{array}$ & $\begin{array}{c}\text { Weight } \\
\text { score } \\
\text { (D) } \\
=(\mathrm{B}) \mathbf{x}(\mathrm{C})\end{array}$ & $\begin{array}{c}\text { Rata-rata } \\
\text { respon } \\
\text { responden } \\
(\mathrm{E}) \\
\end{array}$ & $\begin{array}{c}\text { Weight } \\
\text { score } \\
(\mathbf{F}) \\
=(\mathbf{B}) \mathbf{x}(\mathbf{E})\end{array}$ & $\begin{array}{l}\text { Rata-rata } \\
\text { respon } \\
\text { responden } \\
(\mathbf{G}) \\
\end{array}$ & $\begin{array}{c}\text { Weight } \\
\text { score } \\
(\mathbf{H}) \\
=(\mathbf{B}) \mathbf{x}(\mathbf{G}) \\
\end{array}$ \\
\hline 1 & $\begin{array}{l}\text { Produk yang } \\
\text { ditawarkan } \\
\text { berkualitas }\end{array}$ & 5,12 & 0,26 & 5 & 1,29 & 4 & 1,03 & 5 & 1,29 \\
\hline 2 & $\begin{array}{l}\text { Cat memiliki } \\
\text { daya tutup } \\
\text { yang baik }\end{array}$ & 5,06 & 0,25 & 5 & 1,27 & 4 & 1,02 & 5 & 1,27 \\
\hline 3 & $\begin{array}{l}\text { Harga sesuai } \\
\text { dengan } \\
\text { konsumen }\end{array}$ & 4,90 & 0,25 & 5 & 1,23 & 4 & 0,98 & 4 & 0,98 \\
\hline 4 & $\begin{array}{l}\text { Pemilik toko } \\
\text { bangunan } \\
\text { mau } \\
\text { memberikan } \\
\text { informasi } \\
\end{array}$ & 4,84 & 0,24 & 3 & 0,73 & 4 & 0,97 & 5 & 1,21 \\
\hline & Total & 19,92 & & & 4,51 & & 4,00 & & 4,75 \\
\hline
\end{tabular}

Dari hasil Tabel 10. yang diperoleh, diketahui bahwa berdasarkan pengguna akhir cat tembok, merek yang paling unggul adalah Catylac yaitu sebesar 4.75 , di posisi kedua adalah Ozone dan Vinilex memiliki nilai yang rendah yaitu 4 .

Dari hasil riset juga dapat diketahui perceptual map berdasarkan kedua populasi tersebut.

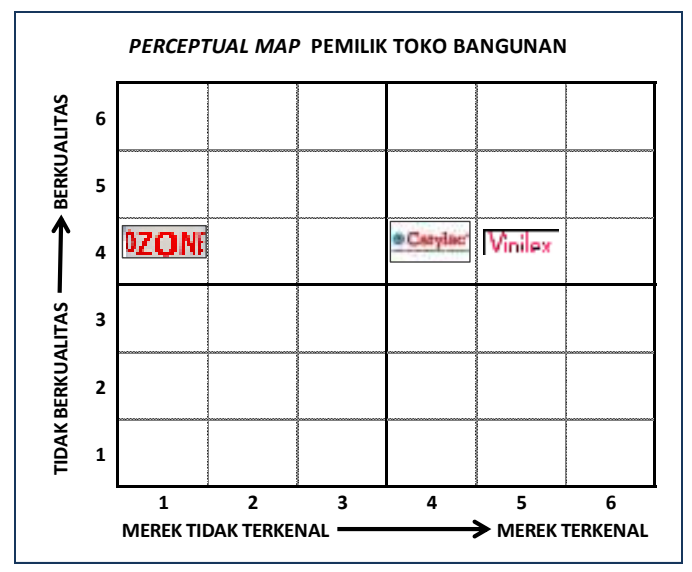

Gambar 4.

Perceptual Map dari Pemilik Toko Bangunan terhadap Produk Cat Ozone, Vinilex dan Catylac 
Gambar 4. menunjukan bahwa ketiga merek tersebut memiliki produk yang berkualitas, namun hanya Ozone yang digolongkan merek tidak terkenal.

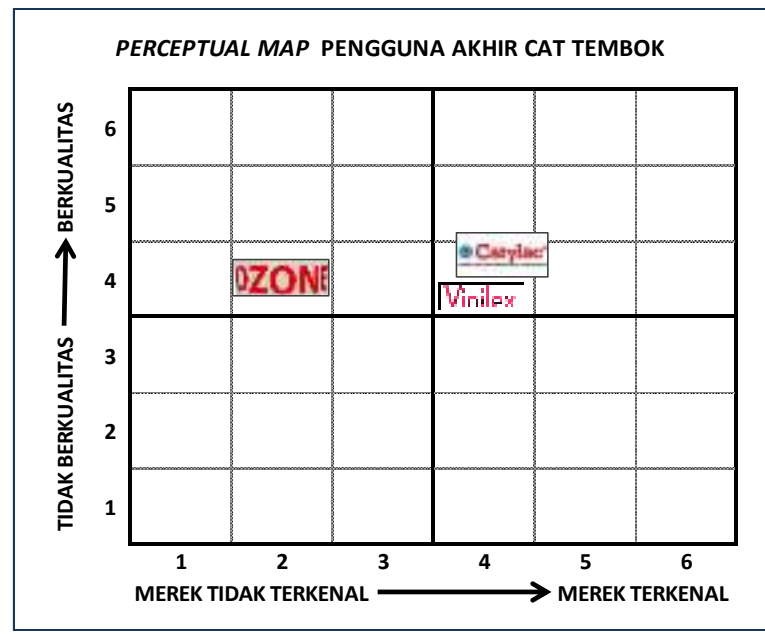

Gambar 5.

Perceptual Map dari Pengguna Akhir Cat Tembok terhadap Produk Cat Ozone, Vinilex dan Catylac

Pada perceptual map pengguna akhir cat tembok (Gambar 5.) hampir sama dengan perceptual map berdasarkan pemilik toko bangunan, ketiga merek merupakan produk yang berkualitas.

Berdasarkan analisis internal, maka dapat diidentifikasi beberapa kekuatan dan kelemahan yang dimiliki oleh perusahaan, antara lain:

- Kekuatan

- Produk cat Ozone memiliki daya tutup paling baik jika dibandingkan dengan Vinilex dan Catylac.

- Produk cat Ozone merupakan cat yang aman bagi kesehatan dan memiliki perlindungan terhadap bakteri.

- Kelemahan

- Tingkat awareness dari produk cat Ozone masih sangat rendah.

- Mayoritas retailer merasa tidak puas terhadap produk cat tembok yang ditawarkan.

- Produk cat Ozone memiliki aroma yang kurang diminati oleh retailer.
- Produk cat Ozone memiliki kehalusan permukaan yang buruk setelah diaplikasikan ke permukaan.

- Distribusi produk cat Ozone untuk wilayah Jadetabek masih sempit.

- Dibandingkan dengan kompetitornya, penawaran promo (hadiah langsung) produk cat Ozone kurang menarik.

- Harga dari produk cat Ozone kurang sesuai menurut pemilik toko bangunan sehingga sulit untuk dijual kepada konsumen.

- Produk cat Ozone hanya dipasarkan kepada toko bangunan tradisional sedangkan kompetitornya sudah masuk ke dalam toko bangunan modern.

\subsection{Sasaran 2012-2014}

Dari hasil analisis tersebut, menyesuaikan keinginan dan kemampuan perusahaan maka sasaran utama yang akan dicapai oleh perusahaan untuk periode 2012 sampai 2014 adalah sebagai berikut (Tabel 11.): 
Tabel 11.

Sasaran Utama Perusahaan untuk Tahun 2012 sampai 2014

\begin{tabular}{|l|r|r||r||}
\hline \multicolumn{1}{|c|}{ Tahun } & \multicolumn{1}{c|}{$\mathbf{2 0 1 2}$} & \multicolumn{1}{c|}{$\mathbf{2 0 1 3}$} & \multicolumn{1}{c|}{$\mathbf{2 0 1 4}$} \\
\hline \hline Market share index & $6,93 \%$ & $10,93 \%$ & $14,93 \%$ \\
\hline \hline Sales (gallon) & 1.905 & 2.095 & 2.134 \\
\hline \hline Ketersediaan toko bangunan & 55 & 92 & 137 \\
\hline
\end{tabular}

\subsection{Alternatif Strategi}

Setelah mengetahui peluang dan ancaman yang dihadapi oleh perusahaan serta kekuatan dan kelemahan yang saat ini dimiliki oleh perusahaan maka dapat disusun TOWS matrix. TOWS matrix tersebut merupakan metode yang digunakan untuk menemukan alternatif strategi bagi perusahan.

Matriks yang terdiri dari kekuatan, kelemahan, peluang dan ancaman ini dapat menghasilkan beberapa jenis strategi yaitu:

- Strengths-Opportunities (SO) adalah strategi yang menggunakan kekuatan internal organisasi untuk meraih keuntungan dari peluang yang ada di pasar.
- Strengths-Threats (ST) adalah strategi yang menggunakan kekuatan internal organisasi untuk mengurangi dampak dari ancaman lingkungan eksternal.

- Weaknesses-Opportunities (WO) adalah strategi untuk mengatasi kelemahan internal yang dimiliki organisasi dengan memanfaatkan peluang yang ada.

- Weaknesses-Threats (WT) adalah strategi yang bertujuan untuk mengurangi dampak dari kelemahan internal organisasi dan ancaman yang ada.

Berikut ini merupakan hasil analisis dari TOWS matrix (Tabel 12.).

Tabel 12.

TOWS Matrix

\begin{tabular}{|c|c|c|}
\hline TOWS Matrix & Strengths $(\mathbf{S})$ & Weakness \\
\hline & $\begin{array}{l}\text { 1. Produk cat Ozone memiliki } \\
\text { daya tutup paling baik jika } \\
\text { dibandingkan dengan Vinilex } \\
\text { dan Catylac. }\end{array}$ & $\begin{array}{l}\text { 1. Tingkat awareness dari produk } \\
\text { Ozone masih sangat rendah. }\end{array}$ \\
\hline & $\begin{array}{l}\text { 2. Produk cat Ozone merupakan } \\
\text { cat yang aman bagi kesehatan } \\
\text { dan memiliki perlindungan } \\
\text { terhadap bakteri. }\end{array}$ & $\begin{array}{l}\text { 2. Mayoritas retailer merasa tidak } \\
\text { puas terhadap produk cat Ozone } \\
\text { yang ditawarkan. }\end{array}$ \\
\hline & & 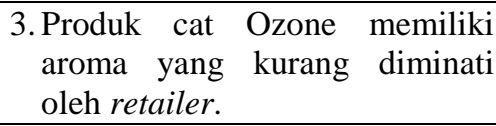 \\
\hline & & $\begin{array}{llr}\text { 4. Produk cat } & \text { Ozone memiliki } \\
\text { kehalusan permukaan yang } & \text { yan } \\
\text { paling } & \text { buruk } & \text { setelah } \\
\text { diaplikasikan. } & \\
\end{array}$ \\
\hline & & $\begin{array}{l}\text { 5. Distribusi produk untuk wilayah } \\
\text { Jadetabek masih sempit. }\end{array}$ \\
\hline & & 6. Dibandingkan \\
\hline
\end{tabular}




\begin{tabular}{|c|c|c|}
\hline & & $\begin{array}{l}\text { kompetitornya, } \\
\text { promo (hadiah langsung) } \\
\text { produk cat Ozone kurang } \\
\text { menarik. }\end{array}$ \\
\hline \multirow[b]{3}{*}{ Opportunities (O) } & \multirow[b]{3}{*}{ SO Strategies } & $\begin{array}{l}\text { 7. Harga dari produk cat Ozone } \\
\text { kurang sesuai menurut pemilik } \\
\text { toko bangunan sehingga sulit } \\
\text { untuk dijual kepada konsumen. }\end{array}$ \\
\hline & & $\begin{array}{l}\text { 8. Produk cat Ozone hanya } \\
\text { dipasarkan pada toko bangunan } \\
\text { tradisional sedangkan } \\
\text { kompetitornya sudah masuk ke } \\
\text { dalam toko bangunan modern. }\end{array}$ \\
\hline & & WO Strategies \\
\hline $\begin{array}{l}\text { 1. Dengan berlakunya peraturan } \\
\text { SNI maka pemerintah akan } \\
\text { memusnahkan beberapa merek } \\
\text { cat tembok non standar } \\
\text { sehingga jumlah merek cat } \\
\text { tembok yang beredar semakin } \\
\text { berkurang. }\end{array}$ & $\begin{array}{l}\text { 1. Memanfaatkan keunggulan } \\
\text { daya tutup yang paling baik } \\
\text { sehingga produk cat Ozone } \\
\text { dapat semakin memperluas jalur } \\
\text { distribusi mengingat permintaan } \\
\text { cat tembok masih banyak dan } \\
\text { terus bertambah serta masih } \\
\text { banyak pasar yang belum } \\
\text { terlayani. (S1, O2, O3, O4, O5, } \\
\text { O6) }\end{array}$ & $\begin{array}{l}\text { 1. Meningkatkan awareness dan } \\
\text { pemahaman kepada masyarakat } \\
\text { tentang pentingnya produk cat } \\
\text { yang sesuai dengan standar. } \\
(\mathrm{W} 1, \mathrm{O} 1, \mathrm{O} 2, \mathrm{O} 4, \mathrm{O} 5)\end{array}$ \\
\hline $\begin{array}{l}\text { 2. Perkiraan pertumbuhan } \\
\text { perumahan pada tahun } 2011 \\
\text { meningkat } 15 \% \text { dan didukung } \\
\text { oleh tren inflasi selama lima } \\
\text { tahun terakhir dapat } \\
\text { meningkatkan permintaan akan } \\
\text { cat tembok di masa yang akan } \\
\text { datang. }\end{array}$ & $\begin{array}{l}\text { 2.Mengkomunikasikan } \\
\text { keunggulan cat Ozone yaitu anti } \\
\text { bakteri, bebas dari kandungan } \\
\text { VOC, aman bagi kesehatan dan } \\
\text { memenuhi standar SNI } \\
\text { sehingga produk cat Ozone } \\
\text { dapat memasuki pasar ekspor } \\
\text { dan mendistribusikannya ke } \\
\text { toko bangunan modern. (S2, } \\
\text { O1, O3, O6) }\end{array}$ & $\begin{array}{l}\text { 2. Memperbaiki kualitas produk } \\
\text { sehingga mampu menghasilkan } \\
\text { produk yang memiliki } \\
\text { kehalusan permukaan yang baik } \\
\text { setelah diaplikasikan. (W2, W4, } \\
\text { O2, O5) }\end{array}$ \\
\hline $\begin{array}{l}\text { 3. Peningkatan pasar cat dan } \\
\text { coating di Asia Pasifik sebesar } \\
5 \% \text { menunjukkan potensi } \\
\text { ekspansi dan ekspor produsen } \\
\text { cat tembok dalam negeri. }\end{array}$ & & $\begin{array}{l}\text { 3.Meningkatkan } \\
\text { komunikasi } \\
\text { lewat media elektronik dan } \\
\text { media cetak serta mengikuti } \\
\text { pameran-pameran dengan } \\
\text { peserta yang berasal dari luar } \\
\text { negeri sehingga keunggulan dari } \\
\text { produk cat lebih dikenal } \\
\text { masyarakat luas. (W1, O1, O2) }\end{array}$ \\
\hline $\begin{array}{l}\text { 4. Indonesia masih harus } \\
\text { mengimpor sekitar } 100.000 \text { ton } \\
\text { per tahun untuk produk cat } \\
\text { tertentu sehingga masih } \\
\text { terdapat potensi pasar yang } \\
\text { belum terlayani. }\end{array}$ & & $\begin{array}{l}\text { 4. Memperluas jalur distribusi } \\
\text { dengan memasarkan produk cat } \\
\text { tembok ke toko bangunan } \\
\text { modern dan toko bangunan semi } \\
\text { modern serta menjadi house } \\
\text { brand dari salah satu retail } \\
\text { modern. (W5, O6) }\end{array}$ \\
\hline
\end{tabular}


5. Sebagian besar dari konsumen melakukan pengecatan ulang kurang dari satu tahun dan satu tahun sekali yang dapat meningkatkan frekuensi pembelian dari produk cat tembok.

6. Banyak dari konsumen tidak hanya membeli produk cat tembok di toko material, namun membeli di toko bangunan modern sehingga produsen cat tembok dapat lebih memperluas jalur distribusi.

Threats (T)

1. Diberlakukannya CAFTA membuat pemain asing mudah masuk dalam industri cat tembok.

\begin{tabular}{||l||l}
\hline & Membuat program undian \\
& berhadiah untuk menarik minat \\
& konsumen mencoba sehingga \\
& mengetahui keunggulan dari \\
& produk. (W6, O1, O2)
\end{tabular}
produk. (W6, O1, O2)

6.Bekerja sama dengan distributor cat tembok ternama untuk membantu pemasaran dan distribusi. (W5, W8, O1, O2, O5)
2. Adanya bea masuk untuk bahan baku cat tembok dari $0 \%$ menjadi $5 \%$ yang dapat menyebabkan harga jual semakin meningat sehingga daya beli masyarakat terhadap produk cat tembok semakin menurun.
2. Menjaga kualitas produk cat Ozone serta harga yang tetap kompetitif untuk dapat bersaing dengan produk-produk luar negeri yang mulai beredar di Indonesia. (S1, S2, W1, W3, W4)
1. Membangun loyalitas konsumen dengan terus mempertahankan kualitas agar mampu bersaing dengan produk yang beredar di pasaran, baik dari dalam negeri maupun luar negeri. (S1, T1, T4, T5, T6)

WT Strategies

1. Menambah sales person dan memberikan pelatihan, pengembangan serta pemahaman mengenai keunggulan produk dan kewajiban membina hubungan baik dengan para pemilik toko bangunan. (W2, T1)

2. Melakukan penelitian mengenai harga yang sesuai dan kompetitif untuk produk cat tembok Ozone di kelas mid tier dengan spesifikasi yang dimilikinya dan memberikan standar harga jual untuk konsumen akhir serta melakukan pemeriksaan secara berkala. Diimbangi dengan merubah persepsi pemilik dan pengguna cat tembok mengenai harga jual produk cat Ozone yang mahal. (W7, T3, T4)

\begin{tabular}{|c|c|c|}
\hline $\begin{array}{l}\text { 3. Perilaku konsumen yang } \\
\text { cenderung } \\
\text { perbandingan harga sebelum } \\
\text { membeli memaksa produsen } \\
\text { membuat harga jual dari produk } \\
\text { cat tembok kompetitif. }\end{array}$ & $\begin{array}{l}\text { 3. Melakukan sosialisasi kepada } \\
\text { masyarakat luas bahwa produk } \\
\text { cat Ozone adalah cat tembok } \\
\text { yang memiliki keunggulan anti } \\
\text { bakteri dan baik untuk } \\
\text { kesehatan dengan harga yang } \\
\text { kompetitif di kelas mid tier. } \\
\text { (S1, S2, T5) }\end{array}$ & $\begin{array}{l}\text { 3. Membuat program promosi } \\
\text { berupa pembagian hadiah } \\
\text { langsung untuk menarik minat } \\
\text { konsumen mencoba produk dan } \\
\text { mengetahui keunggulan dari } \\
\text { produk cat Ozone. (T5, W6) }\end{array}$ \\
\hline $\begin{array}{l}\text { 4. Biaya beralih ke produk cat } \\
\text { tembok lain harmpir tidak ada, } \\
\text { kemudahan informasi serta } \\
\text { banyak bermunculan merek- }\end{array}$ & $\begin{array}{l}\text { 4. Menawarkan keunggulan } \\
\text { bahwa produk cat tembok } \\
\text { Ozone memiliki daya tutup } \\
\text { yang baik sehingga proses }\end{array}$ & $\begin{array}{l}\text { 4. Membangun } \\
\text { konsumen dengan membentuk } \\
\text { komunitas atau megadakan } \\
\text { gathering dengan terget para }\end{array}$ \\
\hline
\end{tabular}




\begin{tabular}{|c|c|c|}
\hline $\begin{array}{l}\text { merek baru membuat konsumen } \\
\text { memiliki banyak pilihan dan } \\
\text { berpindah-pindah ke produk cat } \\
\text { tembok lainnya. }\end{array}$ & $\begin{array}{l}\text { pengecatan menjadi lebih hemat } \\
\text { dan mampu dikombinasikan } \\
\text { dengan wallpaper maupun } \\
\text { bahan lainnya. (S1, S2, T7) }\end{array}$ & $\begin{array}{l}\text { pemilik toko bangunan dan } \\
\text { konsumen produk cat Ozone. } \\
(\mathrm{W} 2, \mathrm{~T} 3, \mathrm{~T} 4, \mathrm{~T} 6)\end{array}$ \\
\hline $\begin{array}{l}\text { 5. Sulit merubah persepsi } \\
\text { masyarakat terhadap produk cat } \\
\text { tembok baru sehingga } \\
\text { menyebabkan merek baru sulit } \\
\text { dijual. }\end{array}$ & & $\begin{array}{l}\text { 5. Membuat promosi dengan } \\
\text { memanfatkan keunggulan- } \\
\text { keunggulan di sektor project } \\
\text { dengan mengkomunikasikan } \\
\text { bahwa produk telah dipakai } \\
\text { pada gedung-gedung ternama. } \\
(\mathrm{W} 1, \mathrm{~T} 5)\end{array}$ \\
\hline $\begin{array}{l}\text { 6. Tindakan yang dilakukan oleh } \\
\text { konsumen ketika merasa kurang } \\
\text { puas atas suatu produk cat } \\
\text { tembok adalah memberitahukan } \\
\text { kepada konsumen lain sehingga } \\
\text { nama baik dari produk cat } \\
\text { tersebut menjadi semakin } \\
\text { buruk, yang mengakibatkan } \\
\text { konsumen beralih ke produk } \\
\text { lainnya. }\end{array}$ & & $\begin{array}{l}\text { 6. Memastikan bahwa produk cat } \\
\text { Ozone diletakkan pada rak-rak } \\
\text { yang disediakan oleh } \\
\text { perusahaan (bukan diisi oleh } \\
\text { produk lain) sehingga mampu } \\
\text { menarik perhatian konsumen } \\
\text { baru. (W1, T5) }\end{array}$ \\
\hline \multirow[t]{2}{*}{$\begin{array}{l}\text { 7. Semakin berkembangnya } \\
\text { produk substitusi berupa } \\
\text { wallpaper, parquet, batu alam, } \\
\text { bata expose dan high pressure } \\
\text { laminate yang mengakibatkan } \\
\text { kemungkinan tergantikannya } \\
\text { fungsi cat tembok di masa yang } \\
\text { akan datang. }\end{array}$} & & $\begin{array}{l}\text { 7. Merancang materi promosi } \\
\text { yang berisikan perbandingan } \\
\text { kualitas produk serta harga yang } \\
\text { diletakkan di toko bangunan dan } \\
\text { brosur promosi produk cat } \\
\text { Ozone yang dibagikan kepada } \\
\text { end user. }\end{array}$ \\
\hline & & $\begin{array}{l}\text { 8. Menyediakan jasa sales } \\
\text { promotion boy/sales promotion } \\
\text { girl untuk melakukan personal } \\
\text { selling dan product knowledge } \\
\text { di toko-toko bangunan tertentu } \\
\text { dan dilakukan secara bergilir. } \\
(\mathrm{W} 1, \mathrm{~T} 5)\end{array}$ \\
\hline
\end{tabular}

Berdasarkan TOWS matrix yang dijabarkan pada Tabel 12. maka dapat dikategorikan menjadi strategi penetrasi pasar, yang merupakan strategi menggunakan produk lama dan pasar lama. Strategi-strategi yang relevan berasal dari hasil analisis TOWS matrix tersebut digabungkan dan dapat dikelompokan menjadi beberapa strategi utama, antara lain:

- Mengkomunikasikan keunggulan dari produk cat Ozone berupa daya tutup yang baik, cat tembok anti bakteri dan sudah digunakan pada gedung-gedung ternama melalui media elektronik, media cetak, dan mengikuti pameran serta memperbaiki kualitasnya.

- Membuat program undian berhadiah dan pembagian hadiah langsung untuk menarik minat konsumen mencoba dan mengetahui keunggulan dari produk.

- Meningkatkan awareness dengan meningkatkan komunikasi lewat media elektronik dan media cetak serta mengikuti pameran-pameran dengan 
peserta yang berasal dari luar negeri sehingga keunggulan dari produk cat lebih dikenal masyarakat.

- Melakukan sosialisasi kepada masyarakat luas bahwa produk cat Ozone adalah cat tembok memiliki keunggulan anti bakteri dan baik untuk kesehatan.

- Membuat promosi dengan memanfaatkan keunggulan-keunggulan disektor project dengan mengkomunikasikan bahwa produk telah dipakai pada gedung-gedung ternama.

- Merancang materi promosi yang berisikan perbandingan kualitas produk serta harga yang diletakan di toko bangunan dan brosur promosi produk cat Ozone yang dibagikan kepada end user.

- Menawarkan keunggulan bahwa produk cat tembok Ozone memiliki daya tutup yang baik sehingga proses pengecatan menjadi lebih hemat dan mampu dikombinasikan dengan wallpaper maupun bahan lainnya.

- Memperbaiki kualitas produk sehingga mampu menghasilkan produk yang memiliki kehalusan permukaan yang baik setelah diaplikasikan.

- Membangun loyalitas konsumen dengan membentuk komunitas atau mengadakan gathering dengan target para pemilik toko bangunan dan konsumen produk cat Ozone serta terus mempertahankan kualitas dan menggunakan harga jual yang kompetitif.

- Membangun loyalitas konsumen dengan membentuk komunitas atau mengadakan gathering dengan target para pemilik toko bangunan dan konsumen produk cat Ozone.

- Memperbaiki kualitas produk sehingga mampu menghasilkan produk yang memiliki kehalusan permukaan yang baik setelah diaplikasikan.

- Melakukan penelitian mengenai harga yang sesuai dan kompetitif untuk produk cat tembok Ozone di kelas mid tier dengan spesifikasi yang dimilikinya dan memberikan standar harga jual untuk konsumen akhir serta melakukan pemeriksaan secara berkala.

- Memperluas jalur distribusi ke toko bangunan modern dan menjadi house brand dari salah satu retail modern dengan menambah sales person dan memberikan pelatihan, pengembangan serta pemahaman mengenai keunggulan produk dan kewajiban membina hubungan baik dengan para pemilik toko bangunan.

- Bekerja sama dengan distributor cat tembok ternama.

- Memperluas jalur distribusi dengan memasarkan produk cat tembok ke toko bangunan modern dan toko bangunan semi modern serta menjadi house brand dari salah satu retail modern.

- Menambah sales person dan memberikan pelatihan, pengembangan serta pemahaman mengenai keunggulan produk dan kewajiban membina hubungan baik dengan para pemilik toko bangunan.

- Menyediakan jasa sales promotion boy/sales promotion girl untuk melakukan personal selling dan product knowladge di toko-toko bangunan tertentu dan dilakukan secara bergilir.

- Mensosialisasikan kepada sales person mengenai ketentuan peletakkan produk cat Ozone pada rak-rak yang telah disediakan oleh perusahaan agar rak tersebut tidak diisi oleh produk cat atau bahan bangunan lain.

- Memastikan bahwa produk cat Ozone dilatakkan pada rak-rak yang disediakan oleh perusahaan (bukan diisi oleh produk lain).

\subsection{Strategi Terpilih}

Berdasarkan dari analisa QSPM, diperoleh nilai tertinggi adalah 
mengkomunikasikan keunggulan dari produk cat Ozone berupa daya tutup yang baik, cat tembok anti bakteri dan sudah digunakan pada gedung-gedung ternama melalui media elektronik, media cetak, dan mengikuti pameran serta memperbaiki kualitas produknya yang diikuti pula dengan memperluas jalur distribusi ke toko bangunan tradisional dan modern dengan nilai 9,151 dan diikuti oleh strategi membangun loyalitas konsumen dengan membentuk komunitas atau mengadakan gathering dengan target para pemilik toko bangunan dan konsumen produk cat Ozone serta terus mempertahankan kualitas produk dan menggunakan harga jual yang kompetitif dan ditambah dengan fasilitas rak display dari perusahaan yang diletakan di toko bangunan dengan nilai 6,049.

Sedangkan pada posisi ketiga adalah untuk strategi menjadi house brand dari salah satu retail modern dan menambah sales person, memberikan pelatihan, pengembangan serta pemahaman mengenai keunggulan produk dan kewajiban membina hubungan baik dengan para pemilik toko bangunan.dengan nilai 4,329.

Dengan demikian dari tiga alternatif strategi tersebut maka dipilih nilai total yang paling tinggi yaitu mengkomunikasikan keunggulan dari produk cat Ozone berupa daya tutup yang baik, cat tembok anti bakteri dan sudah digunakan pada gedung-gedung ternama melalui media elektronik, media cetak, dan mengikuti pameran serta memperbaiki kualitas produknya yang diikuti pula dengan memperluas jalur distribusi ke toko bangunan tradisional dan modern.

\section{KESIMPULAN DAN SARAN}

Dari hasil penelitian dapat disimpulkan bahwa strategi terpilih yaitu mengkomunikasikan keunggulan dari produk cat Ozone berupa daya tutup yang baik, cat tembok anti bakteri dan sudah digunakan pada gedung-gedung ternama melalui media elektronik, media cetak, dan mengikuti pameran serta memperbaiki kualitas produknya yang diikuti pula dengan memperluas jalur distribusi ke toko bangunan tradisional dan modern, sehingga langkah selanjutnya dalam strategi ini adalah menentukan langkah implementasi, langkahlangkah tersebut dibagi kembali melalui bauran pemasaran yang dipilih sebelumnya, langkah-langkah implementasi tersebut adalah:

\section{- Segmenting}

Segmentasi untuk produk cat Ozone akan dibagi beradasrkan firm demographics dan usage behavior. Berdasarkan hasil riset dengan target responden pemilik toko bangunan yang menjual produk cat Ozone maka dapat dilihat pembagian segmentasi dari produk cat Ozone seperti yang tergambar pada tabel 13. dibawah ini.

Tabel 13

Segmentasi Produk Cat Ozone berdasarkan Firm Demographics dan Usage Behavior

\begin{tabular}{|c|c|c|c|c|}
\hline \multirow[t]{2}{*}{ Firm segment profile } & \multicolumn{4}{|c|}{ Segments } \\
\hline & $\mathbf{A}$ & $\mathbf{B}$ & $\mathbf{C}$ & D \\
\hline Sales volume & $>110$ gallon & 76-110 gallon & $41-75$ gallon & 6-40 gallon \\
\hline \multicolumn{5}{|l|}{ Firm Demographics } \\
\hline Locations & Pinggir jalan & $\begin{array}{c}\text { Komplek perumahan / } \\
\text { pinggir jalan }\end{array}$ & $\begin{array}{c}\text { Komplek } \\
\text { perumahan }\end{array}$ & Pinggir jalan \\
\hline Years in business & $>15$ tahun & $>15$ tahun & $\begin{array}{c}\text { 6-10/ } \\
\text { tahun }\end{array}$ & $1-5$ tahun \\
\hline
\end{tabular}




\begin{tabular}{|c|c|c|c|c|}
\hline Characteristics & $\begin{array}{c}\text { Terdapat } \\
\text { toko } \\
\text { bangunan } \\
\text { lainnya }\end{array}$ & Stand alone & Stand alone & $\begin{array}{c}\text { Stand alone / } \\
\text { Terdapat } \\
\text { toko } \\
\text { bangunan } \\
\text { lainnya } \\
\end{array}$ \\
\hline \multicolumn{5}{|l|}{ Usage behavior } \\
\hline Quantity & 41-75 gallon & 41-75 gallon & $\begin{array}{c}41-75 / 6-40 \\
\text { gallon } \\
\end{array}$ & 6-40 gallon \\
\hline Frequency of purchase & $\begin{array}{c}<1 \text { bulan } \\
\text { sekali }\end{array}$ & < < 1 bulan sekali & 1 1 bulan sekali & Tidak tentu \\
\hline Purchase behavior & Konsinyasi & Konsinyasi & $\begin{array}{c}\text { Konsinyasi / } \\
\text { beli putus }\end{array}$ & Konsinyasi \\
\hline
\end{tabular}

\section{- Targeting}

Target utama pemasaran produk cat tembok Ozone adalah toko-toko bangunan tradisional yang menjual cat tembok di wilayah Jadetabek, dengan rata-rata penjualan lebih dari 110 galon sebulan, frekuensi pemesanan cat kurang dari sebulan sekali dengan jumlah yang dipesan 41 sampai 75 galon dan toko tersebut yang sudah berjualan lebih dari 15 tahun, lokasi toko berada dipinggir jalan dengan karakteristik stand alone".

\section{- Positioning}

Produk cat ozone di posisikan sebagai produk cat tembok anti bakteri yang memiliki daya tutup paling baik. Hal tersebut ditujukan agar para konsumen dan pemilik toko bangunan mengetahui keunggulan dari produk Ozone. Hasil preferensi dari pengguna akhir menunjukan bahwa produk yang berkualitas dan daya tutup menjadi preferensi utama dalam pemilihan cat tembok.

Selain strategi implementasi berdasarkan STP, disusun pula strategi implementasi berdasarkan marketing mix, yaitu product, promotion, price dan place seperti yang diuraikan berikut ini.

\section{- Product}

Untuk marketing mix produk maka langkah-langkah yang dapat diimplementasikan adalah sebagai berikut:
- Seperti diketahui dari hasil blind test, produk cat ozone memiliki tingkat kehalusan yang paling buruk, sehingga perusahaan harus memperbaiki kualitas produk sehingga mampu menghasilkan cat tembok yang memiliki kehalusan permukaan baik setelah diaplikasikan. Berdasarkan hasil blind test tersebut diketahui bahwa Vinilex yang memiliki tingkat kehalusan yang baik.

- Memperbanyak variasi warna cat tembok dengan melihat warna cat tembok yang sering digunakan oleh konsumen. Mengingat variasi warna merupakan salah satu fitur produk yang menjadi preferensi dari pengguna akhir cat tembok dalam memilih cat tembok. Saat ini variasi warna dari produk cat Ozone dinilai kurang jika dibandingkan dengan Catylac, walaupun saat ini perusahaan sudah menyediakan mesin tinting.

- Menonjolkan fitur anti bakteri yang dimiliki oleh produk cat Ozone dan bebas dari kandungan VOC (Volatile Organic Compound) yang aman bagi kesehatan. Kedua fitur tersebut yang tidak dimiliki oleh kompetitornya yaitu Vinilex dan Catylac.

- Price

Strategi implementasi harga untuk produk cat Ozone adalah sebagai berikut: 
- Melakukan evaluasi terhadap biayabiaya produksi serta harga pokok penjualan dan biaya pemasaran agar mendapatkan harga jual yang lebih kompetitif

- Melakukan riset mengenai harga jual yang sesuai dengan produk cat Ozone yang bersaing di kelas mid tier namun yang disesuaikan pula dengan keungulan-keunggulan yang dimilikinya sehingga mampu menarik permintaan konsumen.

- Place

Program strategi yang dapat diimplementasikan dan masih bersangkutan dengan strategi tempat yaitu:

- Menyalurkan produk cat Ozone melalui modern retail seperti Depo Bangunan dan Mitra 10 seperti diketahui bahwa pengguna akhir dari cat tembok tidak hanya membeli produk pada toko bangunan tradisional melainkan juga membeli membeli melalui toko bangunan modern.

- Memperluas jalur distribusi ke toko bangunan tradisional di wilayah Jakarta, Depok, Tangerang dan Bekasi sehingga mudah dijangkau oleh konsumen dengan menawarkan keunggulan produk, sistem konsinyasi dan jangka waktu jatuh tempo yang lebih panjang.

- Menyediakan rak display khusus produk cat Ozone yang terdapat di beberapa toko bangunan terpilih untuk menempatkan produk cat Ozone.

- Melakukan negosiasi dengan pemilik toko bangunan untuk peletakan produk cat Ozone pada posisi yang strategis dan mudah terlihat konsumen kita datang ke toko bangunan. Hal tersebut dikarenakan pada beberapa toko bangunan tidak memiliki ketentuan mengenai peletakan produk di rak. Sales person harus mampu meyakinkan pemilik toko bangunan.

\section{- Promotion}

Program promosi untuk cat tembok Ozone yang sesuai dengan strategi terpilih yaitu:

- Memberikan media promosi berupa brosur, spanduk dan media promosi lainnya yang diletakan di toko bangunan dengan menyertakan keunggulan produk berupa daya tutup yang baik dan dilakukan pengecekan secara berkala oleh sales person.

- Bekerja sama dengan pemilik toko bangunan tradisional maupun modern dengan memberikan pelayanan pengecatan gratis dengan meletakan logo produk cat Ozone pada tembok yang diaplikasikan agar pemilik toko bangunan dan pengguna akhir mengetahui kualitas dan merek dari produk cat Ozone.

- Menyertakan nama gedung yang pernah menggunakan produk cat Ozone dalam setiap media promosinya.

- Membangun kerja sama dengan tukang bangunan sebagai sumber infomasi terbesar dari pengguna akhir cat tembok seperti mengadakan gathering.

- Menyertakan nama merek dan logo produk cat Ozone di papan nama proyek pada pembangunan gedung-gedung ternama khususnya pada pembangunan rumah sakit sehingga meningkatkan awareness masyarakat terhadap produk cat Ozone.

- Mengikuti pameran bahan bangunan yang diselenggarakan tiap tahun dengan memberikan promo berupa gratis produk cat dengan pembelian produk cat dalam jumlah tertentu.

- Memberikan program promosi hadiah langsung berupa uang tunai yang tersedia di dalam kemasan cat tembok yang berkisar antara Rp 2.000 sampai Rp. 10.000 . 
- Memberikan harga khusus untuk para pemilik toko bangunan yang memiliki penjualan yang baik.

Berdasarkan pembahasan diatas, maka saran bagi perusahaan untuk mencapai sasaran dan mengimplementasikan strategi yang sudah disusun antara lain:

- Dalam usaha untuk mengimplementasikan program strategi dibutuhkan komitmen dari seluruh karyawan perusahaan serta dukungan dari pihak manajemen agar mampu mencapai sasaran.

- Sistem controlling yang tepat serta evaluasi berkala merupakan salah satu program wajib bagi manajemen perusahaan untuk melihat kefektifitasan dari program strategi yang sudah disusun. Sehingga jika terjadi penyimpangan maka dapat segera diperbaiki.

- Industri cat tembok tergolong memiliki intensitas persaingan yang tinggi sehingga perusahaan dituntut terus melakukan inovasi agar mampu bersaing dengan para kompetitornya serta memperhatikan faktor ekstrenal dan mampu memanfaatkan peluang.

- Perusahaan harus dapat menentukan jalur distribusi yang tepat untuk bermain pada produk cat tembok kelas mid tier karena sebagian besar pemain pada kelas tersebut telah memasuki jalur distribusi melalui toko bangunan modern.

- Program promosi yang baik harus digunakan oleh perusahaan sebelum memperluas jalur distribusi, sehingga pemilik toko bangunan dan masyarakat menjadi aware atas merek dan keunggulan produk cat tembok yang ditawarkan oleh perusahaan. 


\section{DAFTAR PUSTAKA}

Chadwick C. Higgins, James E. Bartlett, H, dan Joe W. Kortlik. 1977. Organizational Research: Determining Appropriate Sample Size in Survey Research.

D.I. Hawkins, David L. Mothersbaugh, dan Roger J. Best. 2007. Consumer Behavior : Building Marketing Strategy, Tenth Edition. New York : McGraw Hill.

David, Fred, R. 2007. Strategic Management: Concept and Cases, Eleventh Edition. New Jersey : Pearson Prentice Hall.

Fanggidae, Apriana H.J. 2006. "Strategi Pemasaran Pariwisata: Segmentation, Target Market, Positioning dan Marketing Mix". Manajemen Usahawan Indonesia vol. 35 no. 01.

Kotler, Amstrong. 1996. Principles of Marketing, Seventh Edition. Pearson Prentice Hall.

Kotler, Keller. 2006. Marketing Management, 12e Edition. Pearson Prentice Hall.

Malhotra, N. K. 2007. Marketing Research : An Applied Orientation. USA. Pearson Prentice Hall.

Milton M. Presley et al. 1973. Advertising Procedure, Sixth Edition. Prentice Hall.

Roger J. Best. 2009. Marketing-Based Management: Strategies for Growing Customer Value and Profitability, Fifth Edition. Pearson Prentice Hall.

Tjiptono. 1996. Pemasaran Jasa, Edisi Pertama. Malang : Bayumedia.

William J.Stanton. 1996. Fundamentals of Marketing. McGraw Hill.

Koran Neraca. "Pertumbuhan Penjualan Cat Terganggu Regulasi", 2 Maret 2011.

http://arsitekku.web.id/index.php/inspirasi/5-survei-cat-favorit-2007-merek-lawas-masih-teratas

http://bataviase.co.id/node/267167

http://bataviase.co.id/node/544075

http://bisniskeuangan.kompas.com/read/2011/01/21/22192143/Pasar.Tunggal.Harus.Diantisipasi.-7

http://economy.okezone.com/read/2011/01/30/320/419505/konsumsi-cat-nasional-diproyeksi-naik

http://elibrary.mb.ipb.ac.id/gdl.php?mod=browse\&op=read\&id=mbipb-12312421421421412-sawiahhaja541

http://id.voi.co.id/berita-indonesia/ekonomi-dan-keuangan/4361-indonesia-tuan-rumah-pameran-produk-cattingkat-asia-pacifik.html

http://id.wikipedia.org/wiki/Produk

http://keuanganinvestasi.blogspot.com/2011/01/kebijakan-pemerintah-rugikan-industri.html

http://puncakmahameru.blogspot.com/2008/12/apa-cat-itu.html

http://swa.co.id/2008/08/pacific-paint-implementasi-sap-business-all-in-one/

http://swa.co.id/2010/06/frost-sullivan-industri-cat-dan-coating-di-asia-pasifik-naik-30-35/

http://www.antaranews.com/berita/1277296350/sni-produk-cat-diharapkan-diterapkan-2011

http://www.bi.go.id

http://www.detikfinance.com/read/2010/12/30/123445/1535929/1016/industri-cat-dan-coating-tak-lagi-lesu

http://www.housing-estate.com/index.php?option=com_content\&task=view\&id=939\&Itemid=137

http://www.lintasberita.com/Dunia/Bisnis/produk-marketing

http://www.perpusdata.com/?p=25

http://www.scribd.com/doc/12325179/ebook-Produksi-Cat-Tembok-Berkualitas

http://www.wartaekonomi.co.id/berita-120465006-prediksi-kenaikan-penjualan-cat.html 